\title{
Ageing Men and Therapeutic Pints in Roddy Doyle's Two Pints
}

\author{
Burcu Gülüim Tekin \\ University of Granada, Spain \\ gulumtekin@gmail.com
}

Copyright (c) 2017 by Burcu Gülüm Tekin. This text may be archived and redistributed both in electronic form and in hard copy, provided that the author and journal are properly cited and no fee is charged for access.

\begin{abstract}
Roddy Doyle is one of the most prominent Irish literary figures of our time. The vicissitudes of Irish middle class families, domestic violence, prominent events in Irish history and Ireland's new multiculturalism are some of the leading themes that he employs in his works. His short story collection Bullfighting (2011) is unique in dealing with a subject matter unfamiliar in his other works: the midlife crises of working-class men. Specifically, the short stories "Recuperation", "Teaching", and "Bullfighting" revolve around middle aged men who have no expectations in life and are entrapped in vicious familial, matrimonial or socio-cultural circles. In a similar way to the aforementioned short stories, Doyle's novel Two Pints (2012) recounts the pub meetings of two Irish men in late middle age. A reflection of each other, these men chat about various subjects such as politics, economy, and dead celebrities, forging bonds as they drink pints together. It could be possible to claim that these two men offer a counterpoint to the male characters found in Bullfighting. They have given up questioning their lives, accepting the facts of life as they are. Bearing all this in mind, this paper aims to analyse the following points: 1) if we compare Bullfighting and his most recent work, Doyle's characters seem to have become older and less pessimistic; 2) the motifs of the pint and the pub meeting function as therapy for his male characters; 3) the tones of both works differ: the bleak tone of the short stories has given way to a humorous tone in the novel. In short, with its aged male characters, Two Pints represents a more light-hearted, humorous version of certain stories in Bullfighting.
\end{abstract}

Key Words. Roddy Doyle, Contemporary Irish Short Fiction, Men's Middle Age Crisis, Masculinity, Hegemonic Masculinity

Resumen. Roddy Doyle es una de las figuras literarias irlandesas más prominentes de nuestro tiempo. Las vicisitudes de las familias irlandesas de clase media, la violencia doméstica, los acontecimientos prominentes de la historia irlandesa y el nuevo multiculturalismo de Irlanda son algunos de los temas principales que emplea en su obra. Su colección de relatos cortos Bullfighting (2011) es única en el tratamiento de un tema desconocido en sus otras obras: las crisis de la mediana edad de los hombres de la clase trabajadora. En concreto, los cuentos "Recuperation", "Teaching", and "Bullfighting" giran alrededor de hombres de mediana edad que no tienen expectativas en la vida y están atrapados en asfixiantes círculos familiares, matrimoniales o socioculturales. De manera similar a los cuentos mencionados, la novela de 
Doyle, Two Pints (2012) relata los encuentros en un pub de dos hombres irlandeses de mediana edad. En sus reflexiones, a menudo similares, estos hombres charlan sobre diversos temas como la política, la economía y las celebridades muertas, forjando lazos mientras beben juntos. Se podría afirmar que estos dos hombres ofrecen un contrapunto a los personajes masculinos encontrados en Bullfighting. Han dejado de cuestionar sus vidas, aceptando los hechos de la vida tal como son. Teniendo en cuenta todo esto, este trabajo pretende analizar los siguientes puntos: 1) si comparamos Bullfighting y su obra más reciente, los personajes de Doyle parecen haber envejecido y ser menos pesimistas; 2) la función terapéutica que ejercen imágenes como la pinta del cerveza y el pub para los personajes masculinos es fundamental ; 3) los tonos de ambas obras difieren: el tono sombrío de los cuentos ha dado paso a un tono humorístico en la novela. En pocas palabras, Two Pints representa a través de personajes masculinos envejecidos una versión más alegre y humorística de ciertas historias de Bullfighting.

Palabras clave. Roddy Doyle, ficción irlandesa contemporánea, crisis de mediana edad en varones, masculinidad, masculinidad hegemónica

In his article "Roddy Doyle: from Barrytown to the GPO" (2000), Brian Donnelly defines Roddy Doyle, one of the most prominent writers of the Celtic Tiger era, in the following terms: "few contemporary Irish writers serve better one of the most fundamental impulses of the novelist since the time of Defoe: to record and preserve the spirit of the times" (23). Doyle's writing not only records the spirit of Ireland but also embraces universal themes, as Doyle explains when summarising the core of his story writing: "knit universal and local qualities together. The themes -domestic violence, music, birth, unemployment, childhood - are universal, recognised everywhere" (qtd. in Martín 1998: 116). However, his two latest works, the short story collection Bullfighting (2011) and the recent novel Two Pints (2012), reveal a thematic shift in Doyle's writing. His previous focus on the multicultural face of Ireland has shifted to a focus on men and the middle age crisis they experience. The male characters of both works are marked by the dilemma of whether or not they measure up to the ideal - or even good enough norm - of what it is to be a successful Irish man. Many of them find that they do not fit the ideal image of masculinity. Although Two More Pints (2014) was published as a sequel to Two Pints, my study focuses on the very first book as it provides more thematic parallelisms to compare with Bullfighting. For example, Two More Pints explores issues such as top models, corrupted politicians, and football referees rather than the major elements of a man's middle age crisis. Therefore, this study aims to analyse Doyle's recent focus on the male mid-life crisis, and explore how it is developed in some stories of Bullfighting and in his longer fiction Two Pints.

In Bullfighting, Doyle touches upon many themes such as marriage, friendship, aging, and loss. Unlike his first short story collection The Deportees and Other Stories (2007), which takes its cue from Ireland's new multicultural condition, Doyle focuses here on the individual spiritual paralysis and mid-life crisis of men. In her book Reading More of Roddy Doyle (2012), Caramine White offers an extensive overview of Doyle's literary production from from the late 1990s onwards. She notes "Doyle shows the same middle-age angst and the same fight between habit and the enchantment of reality" (White 2012: 217). In "The Photograph", for instance, we witness a man's suffering after his best friend's tragic death from cancer. "The Joke", "Ash" and "The Dog" are about the problems of partners, with stressful relationships on the brink of divorce.

The most humorous story in the collection is "Blood". In this story, Doyle introduces us to a vampire who steals his neighbour's hen because he longs for blood. In "The Slave", 
Doyle explores, through the metaphors of "home" (Ireland) and "rat" (outsiders), the dilemma of a middle-aged, middle-class Irish man obsessed with getting rid of the rat that has entered his house. ${ }^{1}$ Giving its name to the collection, the story "Bullfighting" deals with four old best friends going to Spain for a holiday and chatting about their aging selves and women. "Recuperation" signifies Doyle's criticism of modern life in Ireland, particularly in Dublin, by means of his depiction of "[an] outlawed [figure] wandering about the fringes of society" (O'Connor 2004: 18). "Teaching" is a story of an alcoholic teacher, who like the protagonist of "Recuperation", goes through a spiritual stagnation. We find out that he never feels fulfilled in his life and is a wreck in the throes of alcoholism. Specifically, "Bullfighting", "Recuperation" and "Teaching" focus on Irish ageing men whose lives are entrapped in vicious familial, matrimonial or socio-cultural circles.

These three short stories and Two Pints share various thematic points. Two Pints is a chronicle of two middle-aged men's dull and fruitless lives, revealed through their pub conversations. The novel is made up of the dialogues of these two unnamed Irish men. In an online interview with Becky Toyne (2013), Doyle states that the dialogues first appeared in his Facebook account page and were then published in novel form following the positive reactions of his readers. Indeed, the dialogic nature of Doyle's fiction is highly effective, as Brian Donnelly has underlined: "From the start Roddy Doyle's achievement has been to keep the focus and terms of reference of his stories within the day-to-day concerns and awareness of his characters, articulated in their own words without any mediating authorial voice" (Donnelly 2000: 19).

The conversations Doyle records are from daily life: politics, football, celebrities, and wives. Furthermore, the tone of the dialogues is humorous in terms of their use of colloquial speech. The familiarity of speech enables sympathy to develop towards the nameless characters and their easy-going attitude. When compared to the short stories "Recuperation", "Teaching", and "Bullfighting", Doyle's characters in Two Pints seem to have become older and less pessimistic.

Ageing and pessimism are prominent themes of "Recuperation", the first story of Bullfighting. The title of the story is an ironic reference to the protagonist's endless recovery from an unnamed illness. The story opens with Hanahoe, who has to take walks on doctor's orders. The tone of the story is highly bleak and the protagonist's only hope is the idea of grandchildren (although he is not old enough to have any yet). As the narrator indicates "[m]aybe grandkids will do something. If there are any" (Doyle 2011b: 10). We also find out that "[Hanahoe] knows nothing. He doesn't even feel sorry for himself" (10). It is significant that Hanahoe is an unusual name: Tony Hanahoe was a very glamorous Gaelic football player of the 1970s, and he belonged to a famous Dublin team. Doyle may be inspired by this surname for its connotation of past glories, of a youthful glamour and panache that is dated, stale, gone. Significantly, a deep nostalgia for youth is evident in Hanahoe's case: "He never looked women at his age. Until recently. They were always too old" (Doyle 2011b: 10). On the one hand, Hanahoe wishes to recover his youth; certainly he would like to be the object of attraction for young women. On the other hand, he is also scared of assured female heterosexuality as the following quotation suggests: "A young one who'd just started in the job a few weeks before. His leg had touched hers, sitting together. He was surprised when she didn't move. A bit scared. Her leg pressed against his. Nothing sexy about it. Nice, though. The thought" (Doyle 2011b: 8-9).

In spite of his desires, seduction by or of another woman never happens, a seduction which might be the means to end his routine marriage. Tom Shone states that lack of love makes "Recuperation" "among the most desolate things Doyle has written" (Shone 2011). Indeed, the absence of love between Hanahoe and his wife is what magnifies most the pessimistic tone of the story. The Hanahoe couple are almost entirely separated from each 
other both socially and physically. As the following lines indicate, they do not even share the same bedroom any more:

He doesn't know when it changed. He doesn't know when he knew. Before she moved out of the bedroom. They stopped talking. There was nothing dramatic. He's been living alone for years. He doesn't know what happened. There was no one shouting. There was no violence. No one was hit. No one played away from home. He didn't. She didn't. (Doyle 2011b: 8)

This evokes the social and spiritual paralysis that Joyce conveys so well in Dubliners (1914). For instance, in the last story of the collection, the marriage of Gabriel and Gretta Conroy falls into a very similar gap of miscommunication. The absence of "the shouts" and "violence" implies the unwillingness of both Hanahoe and his wife to fight for their marriage. They do not quarrel and they do not even bother to express their feelings. This results in their "living alone" in the same house in different rooms. Hanahoe's marriage is defined by routine and a clear lack of affection and genuine love. His marriage does not signify a bonding love; rather, it resembles a matrimonial asylum to which he is exiled forever.

Likewise, in "Teaching" the absence of love is clearly observed. The narration is in the third person singular and Doyle is employing free indirect discourse. As a result, he elicits sympathy towards the character and the reader can witness the feelings of the protagonist. Doyle introduces us to a middle-aged teacher, who earns his living by teaching "working class kids" (Doyle 2011a: 39). He is neither married nor in a relationship. The narrator admits that the unnamed teacher has had a relationship before, but because of the unbearable thought of the trap of normalcy, such as "the career, the four-bedroom house, [being] the husband or wife, the happiness that was Southside, Catholic respectability" (40), it did not last. Although he is much younger than Hanahoe, and the male characters in "Bullfighting" and Two Pints, the teacher seems to have no expectations in life: "[h]e was alone. He could live" (41). He only has blurred memories of women: "[t]here'd been one woman. She'd said it once: she loved the way he thought" (Doyle 2011a: 39). Deprived of genuine love, the teacher fills the dullness of his life with the significance of his teaching position. Although he sometimes looks at his watch, waiting for the last minute of the class, the only love of his life is his job: "he could feel it - of why he'd loved teaching. Empowerment. He'd loved that word. He'd believed it" (39). Although "empowerment" has become his mantra, in reality he is far from being powerful.

The lack of self-fulfilment is another point of "Teaching". The word "empowerment" is used at various times throughout the plot. The teacher thinks that he empowers the working-class children who are doomed to live hopeless lives, with less opportunities for self and material fulfilment than the upper class milieu. His working motive is attributed to the mission of empowering these children and this explains "why he was there in the school" (39). The narrator's emphasis on the word "empowerment" can be read as the character's urge both to give a meaning to his existence and to come into terms with his life.

The concept of masculinity developed by R.W. Connell is helpful not only to clarify the social disposition of the protagonist in "Teaching", but to shed a light on the other male characters in Doyle's works that this paper analyses. In her leading work Masculinities (1995), gender theorist R. W. Connell defines the term masculinity as "a place in gender relations, the practices through which men and women engage that place in gender, and the effects of these practices in bodily experience, personality and culture" (Connell 1995: 71). In the same study, she introduces the term hegemonic masculinity. Taking its cue from Antonio Gramsci's definition of hegemony, Connell's term can be understood as "the configuration of gender practice which embodies the currently accepted answer to the problem of the 
legitimacy of patriarchy, which guarantees (or is taken to guarantee) the dominant position of men and the subordination of women" (Connell 1995: 77). The social status of the protagonist in "Teaching" does not, however, provide an example of hegemonic masculinity. Due to the absence of promotion in his job, marriage bonding, family ties or religious belief, the teacher does not fit into the cultural definition of the perfect Irish male. Instead, he suffers an identity crisis that appears specifically in middle age, when these accomplishments or requirements are supposed to be manifest. It is not surprising that he tries to boost himself by constantly stating that he gives strength to his students (Doyle 2011a: 40). The writing exercise that he offers to the pupils during his lesson is also highly significant: he scratches out a sentence which he requires the students to continue as an essay. The unfinished sentences on the board can be interpreted as his incomplete or insufficient self-identity which he urges them to define.

In "Teaching" (just as in "Bullfighting" and Two Pints), the consumption of alcohol is significant. The teacher endures his insufficient self and fruitless life by heavy drinking. The narrator indicates "[h]e had an address in his wallet. AA. The address and the times. Alcoholics Anonymous" (39). Furthermore, we learn that he had not gone to Alcoholics Anonymous because "he hadn't felt the need" (40). For this desolate character, extensive alcohol use is a symptom of his sense of failure and it becomes symbolic of his identity crisis. In his work Drinking Cultures (2005), Thomas Wilson traces the close relationship between alcohol consumption and identity in different cultures. He notes pubs are indispensable places in terms of the sustainability of Irish culture. They provide masculine spaces where one's identity and recognition are continuously discussed. Furthermore, he claims "Irish drinking culture, whether in Brooklyn or in Limerick, is a manifestation of the sameness and differentiation of culture and identity" (2005: 3). In a way, alcohol or drinking pints is a survival strategy for Doyle's Irish male characters, to insulate them not only from their daily concerns but also from their lack of overall success and self-assurance in their masculinity. Taking up Homi Bhabba's concept of third space, Åke Persson explores the idea of an alternative territory in Doyle's novels in his essay called "Between Displacement and Renewal: The Third Space in Roddy Doyle's Novels" (2006). He underlines that "[m]any of Doyle's characters share the reality outlined ... and could be said to exist in the third space, thus participating in the type of resistance that this space offers" (2006: 62). Drinking is the third space where Doyle's male characters can propound their insufficient masculinities. In this "third space", they can reconcile with their middle age crisis and agree that they are not the only male figure under the pints' shelter. The last two books of The Barrytown Trilogy often accommodate pub scenes of the main characters. For instance, in The Snapper (1990), the pub provides a masculine domain where the father figure Jimmy Sr. Rabitte can move away from domestic matters (i.e. his daughter Sharon's unexpected pregnancy) and pour out his problems to his peers. Similarly in The Van (1991), the pub is the place where Jimmy Sr. Rabitte and his friend Bimbo spend their earnings from the chipper van business. In their case, the pub can be interpreted as their playground where they can enjoy themselves regardless of their wives' restrains.

In spite of the case of the desolate teacher of the short story "Teaching", who is an alcoholic, the motifs of the pint and the pub meeting function in many instances as a therapy for Doyle's male characters. That is to say, Doyle's men exemplify Connell's idea in Masculinities: "[t]hose who reject the hegemonic pattern have to fight or negotiate their way out" (Connell 1995: 37). In the case of the short story "Bullfighting", drinking comes to the surface as a negotiation strategy against the loss of youth and the lack of self-fulfilment. Just like the other two stories analysed above ("Recuperation" and "Teaching"), "Bullfighting" is told from the third person singular point of view, providing an insight into the middle age crisis of its male characters. The plot is about four childhood friends, now in their mid-forties, 
heading to a vacation in Spain. At the very beginning of the story, the narrator indicates "Donal was forty-eight. So were his friends. He liked the precision of that: all his friends were forty-eight" (Doyle 2011a: 176). Donal's self assurance can be read as a manifestation of his mid-life crisis. He constantly reassures himself that he and his friends are in the same situation. What binds this male group together is not only their age. Despite the fact that "different masculinities are produced in the same cultural or institutional setting" (Connell 1995: 36), they are linked by the same type of masculinity they exhibit. They are all married (but not subordinated by their wives as they can go on holidays individually), financially secure, and unattached to religious values. The narrator summarizes the life of Donal and his friends as follows: "He'd walked out of school in 1977, and straight into a job in the civil service. A few years later, the jobs weren't there. But Donal had never been out of work. And his friends were like him" (Doyle 2011a: 176). Furthermore, as they become old, they go through the mid-life crisis at the same time.

Like "Recuperation", the male characters in "Bullfighting" suffer from the loss of youth. The narrator admits that Donal "couldn't really remember life before children. He couldn't feel it as something he'd once lived. It was too far away, and buried" (Doyle 2011a: 174). The picture of the approaching future becomes more blurred when they feel a deep anxiety at the possibility of meeting a new woman. When their holiday starts in Spain, Donal finds himself conflicted because "[the lounge girl at the hotel] was a woman and a girl - that was the problem. And the attraction" (180). The impossibility of turning the clock back is partially resolved with the therapeutic pints. One of the issues that Donal finds pleasing is that their houses in Ireland are all within walking distance of the pub (177). Finding a pub with long opening hours is their first aim at their holiday destination. The narrator gives another example from Donal's previous holiday with his friends: "They'd found a bar that would let them drink till daylight. They'd had breakfast - Traditional English Breakfast - on the way back to the apartment. He remembered being surprised that he could hold the knife and fork" (181). Furthermore, in their youth "they used to drink all day, days in a row, weekends drunk, into work on Monday, drunk" (181). That is to say, drinking is a rejuvenating habit for those men: it can be interpreted as the only habit that they can indulge in, and which they enjoyed, as youths. Only through drinking at pubs can they maintain their levels of consolation for ageing.

Significantly enough, the feeling that their life may change for the better is never fulfilled in the story. In this sense, the male characters' existence in Doyle's recent work shows a parallel with Samuel Beckett's characters in his famous play Waiting for Godot (1949). Like the lives of the characters in the play (Estragon and Vladimir insistently waiting for someone called Godot who never appears), the lives of Doyle's male fictional characters are apparently devoid of existential meaning. Apparently, the only meaning of their lives derives from their pub meetings full of small talk especially about women, politics, and the economy. This is observed in a dialogue between Donal and his friends, which blends the subjects of politics and women:

-Poor oul' Benazir.

-What a place.

-Mad. Would you have given her one?

$-\mathrm{Oh}$, yeah. Absolutely.

-Too late now, an'anyway.

-She was a fine thing. I liked her headscarf.

-That's the thing though, said Donal. -Women don't wear them here any more.

-Not even at mass. 
-They'll make a comeback, said Ken. -Wait and see. Abercrombie and Fitch or somebody will bring back the headscarf.

-Benazir but, said Gerry. - She was a lot better looking than any of the women politicians in this country.

-That's for sure.

-What about Hillary Clinton?

- No.

-A few years back, maybe. Not now, though.

-She'd be saying the same thing about us.

-She hasn't a clue.

-Would you ride Obama?

-Not unless he was a woman.

-I have a dream. (Doyle 2011a: 184-5)

This brief talk about crucial issues over some pints promises a temporary fulfilment for these male characters. Doyle portrays in an ironic way how unfulfilled masculinities assert their male virile heterosexuality, for example, they chat about having sexual intercourse with the most powerful female political figures of world history. It is also significant that they only stop and think for a moment when the male politician figure is concerned, as Obama's hegemonic masculinity is unalterable for them. At the end of the story, Donal seems to figure out the meaning of his existence, probably with the help of this male bonding over pints: "[t]his was living, he thought. This was happiness" (Doyle 2011a: 202). Clearly, the pint provides these middle aged men with a makeshift strategy to come to terms with their mid-life crisis in a milder way. Another ironic point is Donal's description of happiness, which for him actually is having a discussion while drinking a pint with his friends during a holiday in a foreign country. Although they spend their holidays outside Ireland, they do not explore new experiences but merely duplicate the same behaviour as when they are at home. In this again, Doyle implies their entrapment within the vicious circle of their mundane lives regardless of their changing places. As ageing men, their deteriorating physical shapes do not recover despite the change of their physical location. That is, in the case of their ageing bodies, pubs are unique places to console them in terms of evoking their youth. They take some solace by sharing pints in pubs since it is one of the minor routines they are able to bring and maintain from their young age. Wilson's claim about the significance of the pubs in Irish culture is crucial here: "The pub, or public house, is a particularly important ethnographic arena, wherein drinking practices and other aspects of Irish culture merge, and where the questions of identity and identification continually matter" (Wilson 2005: 3).

In light of this, it is not surprising that Doyle's male characters negotiate their identity crisis as well as their traumatic mid-life problems in the pub. Besides, they witness the same pathetic male experience in their companions and in this way find relief.

Like the stories chosen from Bullfighting, Two Pints is concerned with the mid-age crisis of men in their late forties. As the title suggests, the novel depicts the meetings of two men at the pub in a narrative style made up only of dialogues. Doyle offers the dates of their meetings at the beginning of each dialogue, according to which we figure out that they generally gather twice a week. Those men's dialogues offer an extensively free expression of their thoughts to the extent that we often witness them swearing, as their conversation is lubricated by their pints. The book is a random series of sketches. Nevertheless, the dialogues of the two men are chronologically arranged according to the incidents that occupy the global as well as the local agenda. At times, the conversations contribute to the revelation of these men's life experiences which show parallelisms with some particular issues. Unlike the protagonists of the chosen stories from Bullfighting, the two male characters of Doyle's recent 
work anticipate their old age in a humorous manner. In her work Reading Roddy Doyle (2001), Caramine White explores the primary works of Doyle and she notes that humour is a prevailing literary device in his writing. She suggests that Doyle's characters never give up reacting to events in a hilarious way: "Doyle's characters, in their daily lives, illustrate the healing power of humor. They use humor to diffuse anger and to restore harmony. Numerous scenes include anger, shouting, and potential violence, but the characters' senses of humor prevail" (White 2001: 77).

In the case of the unnamed ageing men of Two Pints, humour plays an important role. Doyle intelligently creates dialogues, enabling his readers to laugh and his characters to sound comical in a serious fashion. For instance, on the occasion that they are discussing the horrifying attack in Oslo (Norway) in the summer of 2010, one of them attempts to reassure the other by referring to the forthcoming football season:

— Thank Christ the football's back in a couple o' weeks.

-What're yeh sayin'? Tha' none o' this would've happened if there'd been football on the telly? (Doyle 2012: 13)

In another example even though one of the men claims that the Irish play bad football: " $[\mathrm{t}] \mathrm{he}$ football's shite. The way we play" (Doyle 2012: 36), they still agree to keep following the football matches and other sporting events. In the following lines, for instance, they chat about the Irish athlete Katie Taylor:

—Did yeh ever think watchin' a girl boxin' the head off another girl would make yeh feel so proud?

—Gas, isn't it? (Doyle 2012: 80)

Obviously, the major subject that they enjoy together is sports. In his article "Men and Masculinities in Late-Modern Ireland" (2001), Henry Ferguson applies Cornell's concept of hegemonic masculinity to the Irish context. He interprets Irish men's interest in sports activities as follows:

The Catholic hierarchy in Ireland expected strict adherence to the compulsory celibacy rule and the form of hegemonic masculinity was cast around celibacy. At the core of this social order was the private family and heterosexual marriage whose sole purpose was procreation, rather than pleasure. Contraception was banned and the birth rate remained extremely high until the 1970s. Even within marriage the Irish man and woman were meant to be chaste. Sex was for procreation. ... [Thus, sexual fulfilment signified] a transgressive act within a dominant discourse which induced shame about the body and 'unruly passions'. Allied to this, sport played a key role in the production of the disciplined, Catholic, self-reliant Irish male body. (Ferguson 2001: 120)

The predominant cultural norm, which might be summarized as "an Irish man should know about sports" is also valid in the case of these two men. Notably, sports and sharing pints are strategies for overlooking their impending old age. In another anecdote their disengaged attitude continues as follows: "- -But, now, all the EU leaders meetin' in Brussels tomorrow, —Ah, fuck off. I'm not interested in those cunts" (Doyle 2012: 12).

The bleak tone of the Bullfighting stories is replaced by a more vivid tone in Two Pints. As we see in the novel, the two men are managing to accept their decaying lives as they are. When they talk about dead singers such as Amy Winehouse or Whitney Houston, they 
evaluate them not only for the quality of their own voices but also for their age. Furthermore, they find personal echoes between the celebrities and themselves. One of them compares Winehouse to his oldest child in the following lines:

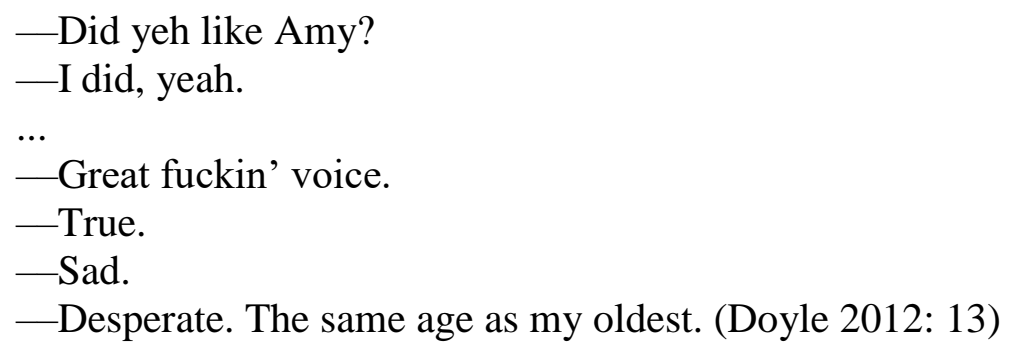

When closely looked, the above dialogue not only reveals the sad feelings towards the sudden death of a popular young singer; but also portrays vicariously the experience of losing a loved one. Furthermore, the man's eldest child is the same age as Winehouse. In other words, he is sensitive as he can imagine that the death of a child must weigh heavily on a parent. Apart from his empathy, he himself is comparable to Winehouse's father, and that means he is, by any measure, no longer young. In another example, they relieve themselves by claiming that being in their forties do not count as an old age period as follows:

- [Whitney Houston] was forty-eight.

-But she was always a young one. D'yeh know what I mean?

—An' forty-eight's young these days anyway. (Doyle 2012: 54)

In any case, both men are similar to the male characters portrayed in the Bullfighting stories in that they do not consider their marriages as a joyous part of their lives but as an accidental bonding. They come across as if they were doomed to be married and submit to their unchangeable fate. The following dialogues reveal how these men entered into their routine marriages in the first place:

- I met the wife durin' 'Love To Love You Baby'.

-You asked her up.

- No.

- No?

- I asked another young one an' she said, Fuck off an' ask me friend.

-An' that was the wife.

- Her sister. An' she told me to fuck off as well. So. Anyway. Here we are.

(Doyle 2012: 62)

The dialogue suggests that this man's matrimony was actually accidental. One of the men picked up his partner and agreed to be with her just because she was the only one who did not reject his dance proposal. While the phrase "the wife" commonly substitutes the phrase "my wife" in colloquial Hiberno-English, it can indicate an entire stereotype for a gender role. Therefore, it can be interpreted as a linguistic indicator of stereotyping to dehumanise the spouse in the excerpt above. Besides, the man himself distances himself from his matrimonial bondage by using the phrase "the wife" instead of stating "my wife" (62).

Not surprisingly, politics and economy serve an important role in the dialogues of these two men. They think they still find some points to "hate Brits" (Doyle 2012: 41), such as the Queen's visit to Northern Ireland (70). Furthermore, when one of them asks the other how long the Euro will last, the other answers that he has enough until another pint (38). We 
also hear them cursing against politics or the economic situation in Ireland. In his review of Two Pints for The Telegraph, Martin Chilton states that although these characters' "conversations occasionally become angry, harmony is always restored over a pint" (Chilton 2013). This also explains why these men underline that they really need a pint (Doyle 2012: 20). Although they are not fully content with their lives and well aware of the fact that they are not the best representatives of the socially constructed superior position of men as compared with other men, these men sound more optimistic in their way of accepting the reality of life than the male characters of the Bullfighting collection. Unlike the discontented protagonist of "Recuperation", the alcoholic male figure in "Teaching", or the hopeless men in "Bullfighting", these drinkers seem to have become older but less pessimistic. Besides, far from being a mere addiction, sharing a couple of pints functions as a therapy for them. In Two Pints the male characters do not seem to have gained many insights in the process of growing older. Yet, their dialogues reflect the fact that they approve of getting old in a placid manner. The pessimistic tone of the Bullfighting stories, also signalled through its black cover, is here substituted by the pink and blue patterned cover of Two Pints, where we see the two men sitting on the bar chairs with their backs turned to the readers. They face the bar and look into their pints as if the ultimate answer lies there. This signifies their indifference to the facts of their lives while their humpy posture suggests their ultimate acceptance of it.

Whereas Doyle's previous work revolved around international or cultural subjects such as history, domestic violence, inward migration to Ireland, and Dublin's working class lives, Doyle turns his recent writing to a different subject. Bullfighting gives a bleak portrayal of the middle age crisis of Irish men. They struggle against upcoming old age with various strategies, mainly drinking pints. Faced by a lack of existential meaning, they suffer and complain about their decaying lives. However, in Two Pints, Doyle offers two male figures as a counterpoint to the male characters found in Bulfighting. They seem more carefree and content about their passing middle age. In short, with its aged male characters, Two Pints represents a more light-hearted, humorous version of certain stories from Bullfighting.

\section{Notes}

1 For a comparative analysis of this short story see the essay "The 'Others' of the Celtic Tiger: Intercultural Encounters in Roddy Doyle's Short Fiction” (2014) by Pilar Villar-Argáiz and Burcu Gülüm Tekin.

2 For an extensive analysis of this short story see the book chapter "An Analysis of Modern Day Dubliners in Roddy Doyle’s 'Recuperation’” (2016) by Burcu Gülüm Tekin.

\section{Works cited}

Chilton, Martin. 2013. "Two Pints by Roddy Doyle”. The Telegraph. 2 January. http://www.telegraph.co.uk/culture/books/fictionreviews/9774199/Two-Pints-byRoddy-Doyle-review.html [retrieved: 28/04/2013]

Connell, R. W. 1995. Masculinities. Cambridge: Polity Press.

Donnelly, Brian. 2000. "Roddy Doyle: from Barrytown to the GPO." Irish University Review, 30.1. 17-31.

Doyle, Roddy. 2011a. "Bullfighting”. Bullfighting. New York: Viking. 174-202. 2011b. "Recuperation". Bullfighting. New York: Viking . 1-12. 2011c. "Teaching". Bullfighting. New York: Viking. 29-42. 2012. Two Pints. London: Jonathan Cape. 
Ferguson, Herry. 2001. "Men and Masculinities in Late-Modern Ireland". A Man's World: Changing Men's Practices in a Globalized World. Eds. Bob Pease and Keith Pringle. New York: St. Martin's Press. 118- 134.

Martín, Sara. 1998. "Adapting The Barrytown Trilogy: An interview with Roddy Doyle." Links \& Letters, 5. 111-118.

O'Connor, Frank. 2004 (1963). The Lonely Voice: A Study of the Short Story. Hoboken: Melville House.

Persson, Åke. 2006. "Between Displacement and Renewal: The Third Space in Roddy Doyle's Novels." Nordic Irish Studies, 5. 59-71.

Shone, Tom. 2011. "Roddy Doyle's Dubliners". New York Times Book Review. 27 May. http://www.nytimes.com/2011/05/29/books/review/book-review-Bullfighting-byroddy-doyle.html [retrieved: 28/04/2013].

Tekin, Burcu Gülüm. 2016. "An Analysis of Modern Day Dubliners in Roddy Doyle's 'Recuperation'". Words of Crisis Crisis of Words: Ireland and the Representation of Critical Times. Eds. María Losada-Friend, Auxiliadora Pérez-Vides, Pilar Ron-Vaz. Newcastle: Cambridge Scholars Publishing. 193-206.

Toyne, Becky. 2013. "Kobo Books - Online Interview with Roddy Doyle". http://www.youtube.com/watch?v=gl4HFUWlvhs [retrieved: 28/04/2013]

Villar-Argáiz, Pilar and Burcu Gülüm Tekin. 2014. "The 'Others' of the Celtic Tiger: Intercultural Encounters in Roddy Doyle's Short Fiction”. Revista Canaria de Estudios Ingleses, 68. 157-171.

White, Caramine. 2001. Reading Roddy Doyle. Syracuse: Syracuse University Press. 2012. Reading More of Roddy Doyle. Dublin: Glasnevin.

Wilson, Thomas M. 2005. Drinking Cultures. Oxford: Berg.

Received: 27 October $2016 \quad$ Revised version accepted: 25 January 2017

Burcu Gülüm Tekin earned her bachelor and master degrees in American Culture and Literature from University of Istanbul, Turkey. She later obtained a master diploma at the University of Granada, Spain with a thesis on the representation of female characters in James Joyce's short fiction. She is currently conducting her Ph.D. at the University of Granada on Roddy Doyle's work, by particularly focusing on his portrayal of women, especially mothers. She has presented papers related to Doyle's work in various conferences (i.e. EFACIS, AEDEI and the New Voices Conference). Her research has been published in academic journals such as, Estudios Irlandeses, Revista Canaria de Estudios Ingleses, and Studi Irlandesi. Her essays have been published in volumes called Words of Crisis, Crisis of Words: Ireland and the Representation of Critical Times (2016); and Ireland and Dysfunction Critical Explorations in Literature and Film (2017). 